\title{
THE EFFECTS OF HUMAN RESOURCE, MARKETING AND MANUFACTURING PERFORMANCE ON FINANCIAL PERFORMANCE
}

Ayse TANSEL CETIN

Gebze Institute of Technology, TR

\begin{abstract}
In today's competitive environment, in order for a company to exist, it must continually improve its performance by reducing cost, improving quality and productivity, and easy access to market. Therefore, businesses have to know the factors which affect their performance and manage these factors effectively in order to survive and face an ever increasing competitive pressure. The purpose of this article is to explore the effects of the human resource management, marketing and manufacturing performance on financial performance by considering marketing performance and manufacturing performance as mediating variables in the relationships between human resource management and financial performance. For this purpose, data were obtained from 110 firms within and around the Kocaeli Industrial Region. In order to test the hypotheses of this study, correlation and regression analyses were performed. Results of correlation analysis revealed that all variables are positively related to both financial performance and to each other. The findings from regression analysis reveal that both marketing and manufacturing performance have statistically significant positive effect on a firm's financial performance. Human resource management does not have any statistically significant effect on a firm's financial performance. The effect of human resource management on financial performance is overshadowed. The results of regression analysis shows that manufacturing performance fully mediates and marketing performance partially mediates the relationship between the human resource management and financial performance
\end{abstract}

Keywords: The performance of the marketing, Human resource, Manufacturing, Financial performance

\section{INTRODUCTION}

Today, company managers have realized the importance of involving the whole organization in making strategic decisions in order to compete in worldwide scale. A study by Porter (1990) indicates that business that accomplishes international leadership employs strategies that take advantage of their distinctive competencies. These capabilities include designing new products, installing new production technologies, adapting training programs, using quality control techniques, and improving supplier relationships. Some innovations result from revolutionary changes in strategy, but others are a series of small, incremental changes. Over time, more and more countries have joined the global economic competition. New technology, new products, new markets, new manufacturing techniques and new management concepts are continuously emerging to change an industrial competitive advantage $(\mathrm{Li}, 2000)$. Therefore, the impact of sources of competitiveness (human resource management, marketing and manufacturing performance) on organizational performance is still an empirical question of significance, especially when the concept is applied to the emerging economies. Human resource management, marketing and manufacturing performance are the most crucial factors in obtaining and sustaining competitive advantage. For this reason, the purpose of this article is to explore the effects of the human resource management, marketing and manufacturing performance on financial performance in Turkish manufacturing firms. In this study, we also examined the importance of both a firm's marketing and manufacturing performance as mediating variables of relationships between human resource management and financial performance. In order to test the hypotheses of this study, correlation and regression analyses were performed. Results of correlation analysis revealed that all variables are positively related to both 
financial performance and to each other. The findings from regression analysis reveal that both marketing and manufacturing performance have statistically significant positive effect on a firm's financial performance. Human resource management does not have any statistically significant effect on a firm's financial performance. Namely, the effect of human resource on financial performance is overshadowed. Result of regression analysis shows that manufacturing performance fully mediated and marketing performance partially mediated in the relationship between the human resource management and financial performance.

This article consists of six sections. The second section surveys the literature about the human resource management, the performance of marketing, manufacturing and financial performance. The relationship between financial performance and variables, research hypothesis is presented in the third section. The fourth section is dedicated to methodology, measures, and tests of the hypothesis. Conclusion is presented in the next section. The limitations of the study and future research directions are discussed in the last section.

\section{LITERATURE REVIEW}

\section{Human Resource Management}

The most valuable resource any organization has is its employees (Evans and Lindsay, 1996; Simerly, 1997). Better economic performance requires greater organizational efficiencies in order to accomplish worldwide competitiveness (Simerly, 1997). The human resource is the only competence that competitors can not replicate (Evans and Lindsay, 1996) Employee empowerment; job enlargement, labor- management relationship improvement, and performance measure criteria development were considered fundamentals of human resource development $(\mathrm{Li}, 2000)$

Human resource management that identifies the skills of each person, motivates employees to use those skills, and seats the proper individuals at the key positions will have an enormous effect on the alliance's efficiency (Lajara et al., 2003).

Human resource activities are mostly accepted to play a central role in connecting employee capabilities with the performance requirements of a firm, the specific form of this correlation is still open to discuss on (Youndth et al, 1996, pg.837).

"According to Flamholtz\&Lacey, (1981) Human resource management practices make investments in human capital. The notion of human capital is that people possess skills, experience, and knowledge that have economic value to firms"(Snell and Dean, 1992, pg.468).

"Lado and Wilson (1994) define a human resource system "....as a set of distinct but interrelated activities, functions, and processes that are directed at attracting, developing, and maintaining a firm's human resources"(Ahmad\&Schroeder, 2003)".

According to Goold\&Quinn (1990), "Human resource management is one of the primary mechanisms by which managers integrate the actions of individuals to keep their behavior congruent with the interests of the firm".

\section{Marketing Performance}

According to Kotler and Andreasen,(1996) marketing is defined as "the process of planning and executing programmed designed, make, and maintain beneficial exchange relationships with target audiences for the purposes of satisfying individual and organizational objectives." Marketing proficiency of a firm is defined as an ability to understand who the customer are and how to meet their needs better than the competitors can (Hill, 1994; Conant et al., 1990; Li, 2000).

According to Houston (1986), the marketing concept centers on the management of market "exchange" between customers and organizations. It helps organizations to accomplish exchangedetermined goals more efficiently. The marketing notion entails firms to receive a pro-active 
approach to engage in business and be sensitive to customer demands and market changes (Kohli and Jaworski, 1990).

Marketing links requirements from the exterior environment with the important functional areas within the organization (Gummesson, 1991) and contributes to developing priorities of quality improvement and providing a road map for utilizing corporation resources (Lai and Cheng, 2005).

Measuring marketing performance has been a vital concern in marketing and remains a very important issue for many companies, mainly for those in industries where marketing expenditures are important (Morgan et al, 2002). Both academics and managers are interested in comprehensive understanding of the marketing performance. The correct measurement of marketing performance is a significant matter for they. Marketing performance is a multidimensional process. Marketing performance, concerns, awareness, and reactions to realized positional advantages achieved (Day and Nedungadi, 1994). According to Walker and Ruekert, (1987) the marketing literature has focused on three sizes of marketing performance: effectiveness, the extent to which organizational aims and goals are achieved, efficiency, the relationship between performance outcomes and the inputs required to accomplish them, and adaptiveness, the capability of the business to meet environmental changes (Morgan, et al 2002).

\section{Manufacturing Performance}

Over the last decade, the concept of manufacturing competence has received increased attention from managers. Manufacturing is one of many functional areas in a business unit. Manufacturing ability has to be assessed on whether its functional strengths support the competitive priorities that grow out of business strategy. Manufacturing function significantly contributes to the establishment and maintenance of the organization's competitive position (Hayes and Upton, 1988).

"The major topic of manufacturing competencies described in the literature is manufacturers' choice of emphasis among key tasks. These tasks include materials management, production planning and control, capacity management, etc. Materials management concerns suppliers, inventories, production level, staffing patterns, and distribution. Decisions in these areas affect the entire organization, either directly or indirectly. Production planning and control, on the other hand, focus on planning, scheduling, process quality control, and production cost reduction. An appropriate capacity level and good capacity management enable a firm to meet current and future demand and seize opportunities for growth and profits" (Li, 2000, pg.302).

\section{Financial Performance}

According to Venkatraman and Ramanujam (1986) the core of the concept of business performance consists of outcome-based financial indicators. They refer to these indicators as the financial performance, while others use the term economic performance (Cavusgil and Zou,1994; Bello and Gilliland 1997).

A company's market share and financial performance are very important to the survival of a company. The measures of performance of this study include sales volume, profits, market share, return on investment (ROI), productivity and customer satisfaction. These measures have been used in existing literature (Clark, 1982; Hill and Jones, 1989; Nobel, 1995; Li, 2000). ROI is consistent with historic emphasis on the contribution of manufacturing on cost-oriented goals. Manufacturing costs have substantial impact on ROI by virtue of their inclusion in the cost of goods sold figures in a revenue and loss statement (Clark, 1982; Hill and Jones, 1989). In addition, those "first to market" firms have an advantage in capturing a larger market share, which can positively affect the income of a firm ( $\mathrm{Li}, 2000)$. 


\section{RESEARCH HYPOTHESES}

\section{Human Resource Management and Marketing Performance}

Marketing skills become a factor in the training required for a wide variety of staff, regardless of their "primary function". Furthermore, the job descriptions of the part-time marketers should be written to incorporate those elements of marketing activity which the staff is expected to undertake. A successful implementation of interactive marketing will depend upon a high level of cooperation between the marketing and human resource functions within the organization. Where interactive marketing has been implemented, as it is to be expected that marketing and human resource strategies will be substantially integrated since one of the key roles of the human resource management function will be to attract, recruit, train, and motivate staff who are "marketing aware" and who can act as competent part-time marketers the professional marketing staff will have to cooperate with the human resource management function in the processes of internal communications, internal marketing, and staff training and development (Brennan, et al.,pg.148,2003).

Harris and Ogbonna's (2001) research results show that the association between HRM and performance is mediated by the extent of market orientation exhibited by the organization. Hence, HRM can be viewed as an antecedent to market orientation. These findings lead to a number of conclusions and implications for both theorists and practitioners. Therefore, human resource management is expected to have a positive effect on marketing performance.

We propose the first hypothesis 1 to be:

Hypothesis1. Human Resource Management of a firm is positively related to its marketing performance.

\section{Human Resource Management and Manufacturing Performance}

A number of studies have been conducted to examine the impact of human resource management practices on manufacturing performance. Jayaram et al (1999) explore the relationships among underlying dimensions of human resource management practices and manufacturing performance. The results of their study show that HRM factors are related to manufacturing performance measures. Their study found support for the proposed framework, suggesting that human resource management practices can be grouped into five distinct factors, four of which are associated with specific manufacturing competitive dimensions: quality, flexibility, cost and time. The four priorityspecific HRM factors are strongly related to their respective manufacturing performance dimensions.

Challis et al (2005) explored the relationships between facets of integrated manufacturing, consisting of total quality management, timely and advanced manufacturing technology, various organizational improvement initiatives, such as in leadership, teams, human resource management, and benchmarking, and employee and manufacturing performance. Results from a survey show that the integrated manufacturing facets of total quality management and timeliness are significantly connected with organizational and human resource practices while advanced manufacturing technology is weakly connected with a narrower range of practices. Organizational and human resource practices also explain a significant additional variance in both employee and manufacturing performance, which is explained above by integrated manufacturing facets. Furthermore, by partitioning the large data set into three sections using manufacturing performance as a cutting variable, it is seen that high-performing firms place considerably more emphasis on 'soft' human resource management practices and rely on total quality management principles half as much as lowperforming firms (Challis et al, 2005).

We propose the second hypothesis to be: 
Hypothesis2. Human Resource Management of a firm is positively related to its manufacturing performance.

\section{Human Resource Management and Financial Performance}

The impact of Human resource management practices on performance has been the subject of much attention over many years. Over the years, researchers have suggested many human resource management practices that have the potential to improve and maintain organizational performance (Ahmad\&Schroeder, 2003). Many researchers investigated the effect of the HRM practices on firm performance. Their research results show that human resource performance have statistical influence on the financial performance (Delaney and Huselid, 1996; Arthur, 1994; MacDuffie 1995; Batt 2002; Levine\&Tyson, 1990).

Accordingly, Becker\&Huselid's (1998) researches indicate that selectivity in staffing is positively associated with firm performance. Many studies confirm that comprehensive selection and training activities are often associated with both productivity and firm performance. (Kleiner et al., 1987; Terspstra\&Rozell, 1993). Recently most researchers (Arthur, 1994; Huselid, 1995; MacDuffie, 1995) have found that bundles or systems of HR practices had more influence on performance than individual practices working in isolation (Youndth et al, 1996, pg.837).

Arthur $(1992,1994)$ found that HR practices focused on increasing employee commitment were related to higher performance. Conversely, he also found that HR practices that focused on control, efficiency, and the reduction of employee skills and discretion were associated with increased turnover and poorer manufacturing performance (Youndth et al, 1996). Human resource function has a direct effect on bottom line consequences and must be aligned with corporate purposes. Effective management of human resource may be the ultimate determinant of organizational performance (Liao, 2005).

We propose the hypothesis to be:

Hypothesis3. Human Resource Management of a firm is positively related to its financial performance.

\section{Marketing Performance and Financial Performance}

A number of studies have been conducted to examine the impact of marketing performance on financial performance. Conant et al. (1990); Hill and Jones (1989); Krajewski and Ritzman's (1996) research results show that marketing performance has a significant effect on financial performance. Day and Fahey (1988); Kaplan and Norton's (1993) study results revealed that the sales performance of the firm in combination with the cost of sales in it is market (s) will determine financial performance outcomes in terms of revenue, cash flow, and profitability.

Also, Szymanski et al (1993) concluded that, on average, market share is positively related to profitability. Capon et al. (1990) found that both market share and sales growth are positively associated with financial performance. Ngai and Ellis [19] argue that company performance is related to marketing practices. According to Conant et al, (1990); Hill and Jones, (1989), "Emphasizing responsiveness, meeting the customer's needs through providing pre-sale, transactional, and post-sale services can improve sales volume and financial performance" ( $\mathrm{Li}$, 2000,pg.3001). Furthermore, marketing researches show that various decision areas in marketing, such as the product, price, place, and promotion in relation to marketing outcomes which affect organizational performance (Perreault and McCarthy, 1999).

Raju and Lonial's (2002) studies show that new product/service development, research and development of new innovations, building competitive advantage, and creating new markets are significantly important key marketing strategies. These are significantly related to financial performance. 
It is obvious that improvements in marketing performance result in improvements in the financial performance of a firm. We propose the fourth hypothesis to be:

Hypothesis 4. The marketing performance of a firm has a positive effect on a firm's financial performance.

\section{Manufacturing Performance and Financial Performance}

The concept of manufacturing competence is found to be influential in determining the business performance. Kim and Arnold's (1993) study showed that manufacturing competence has a powerful effect on business performance. Also, the manufacturing competence appears to have a more significant statistical relationship with some performance measurements, such as the return on assets and the return on sales, than with other manufacturing matters, but not equally to all the financial and market performance. Moreover, numerous studies reveal that highly competent manufacturing should yield better business performance.(Skinner,1969; Buffa,1984; Swamidass, and Newell, 1987; Kim and Arnold,1993) Roth and Miller,1990 found that business performance is affected not only by successful implementation of manufacturing strategy, but also by many other factors, such as environment, general management strength, and other functional strategies. Kim and Arnold (1993) found that return on assets and profit ratios have a statistically significant relationship with manufacturing competence. However, growth rate and market share do not appear to have any significant relationship with the competence index. Their results show that different performance measures, such as ROA, growth rate and market share may be differently affected by manufacturing competence. Likewise, Wang's (1993) study shows that manufacturing performance has statistically significant effect on financial performance.

It is obvious that improvements in manufacturing performance result in improvements in the financial performance of a firm. Therefore, the following hypothesis can be formulated:

Hypothesis 5. Manufacturing performance of a firm has a positive effect on a firm's financial performance.

Many studies have been conducted to examine the impact of human resource management on marketing and manufacturing performance in literature (Brennan et al, 2003; Jayaram et al, 1999). On the basis of existing literature, we can claim that marketing and manufacturing performance mediate the relationship between human resource management and financial performance. According to Baron and Kenny (1986), some conditions are necessary for mediation. Baron and Kenny (1986) outline the conditions in which mediators should be tested: (a) the independent variable (human resource management in our study) should be related to the dependent variable (financial performance), (b) the independent variable should be related to the mediator (marketing and manufacturing performance), (c) the mediator should be related to the dependent variable, (d) when mediator is added in to the model as one of the predictors of the dependent variable, the effect of the independent variable on the dependent variable should become statistically insignificant (fully mediated) or decrease (partially mediated) (Mount et al.,2006). It is obvious that improvements in human resource management performance result in improvements in marketing and manufacturing performance. Therefore, the following hypothesis can be formulated:

Hypothesis 6. Marketing performance will mediate the relationship between human resource management and financial performance.

Hypothesis 7. Manufacturing performance will mediate the relationship between human resource management and financial performance.

All the relationships among the variables are illustrated in Figure 1. 


\section{Figure 1. Conceptual Model}

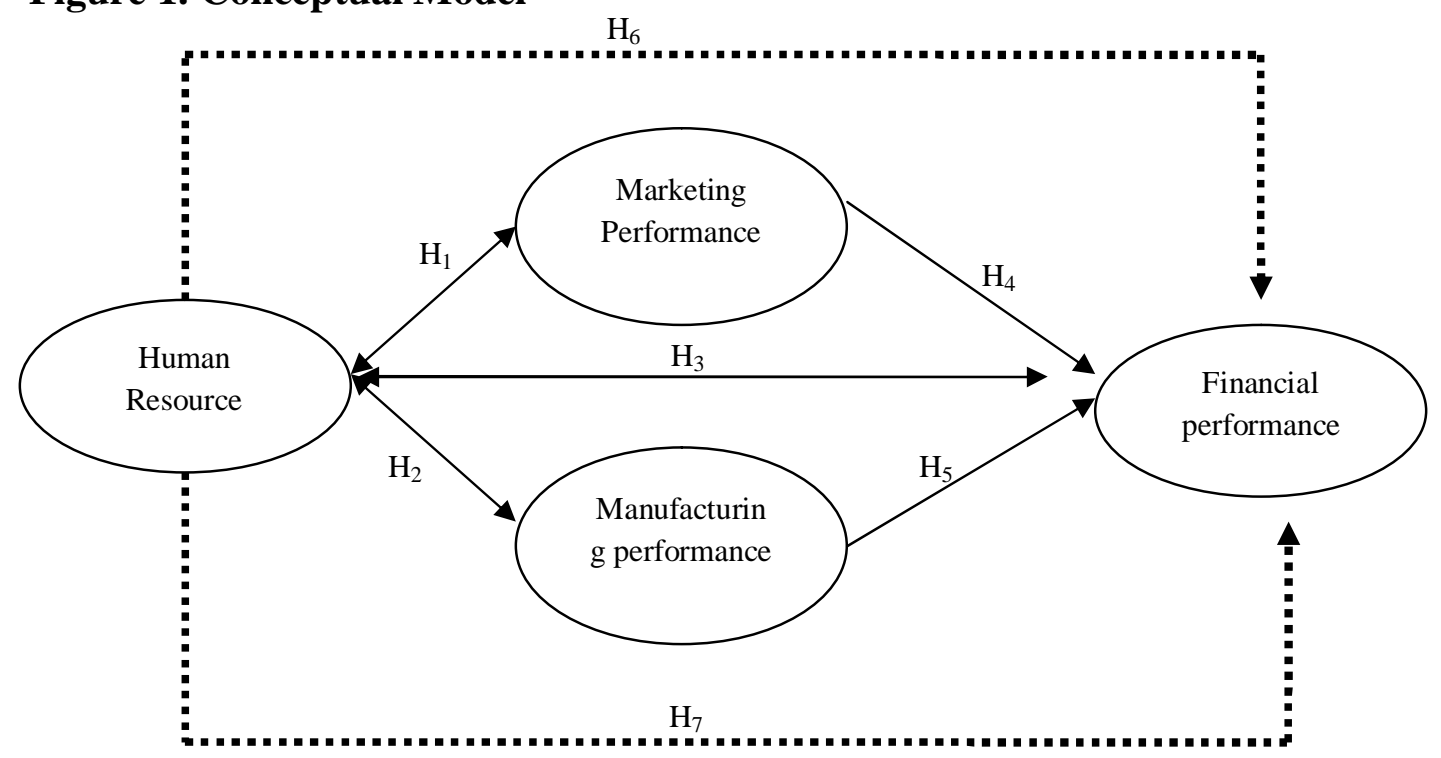

Full Mediation

\section{RESEARCH METHODOLOGY}

\section{Measure Development}

All constructs were adapted from existing scales in the literature. A five point Likert scale was used to collect data. Most statements had response categories ranging from 'strongly disagree' (1) to 'strongly agree' (5). Human resource management was measured by eight-item questionnaire adapted from Evans and Lindsay, (1996); Simerly (1997); Hill (1994). In order to measure marketing performance, six-item scale developed by Li (200); Conant et al., (1990); Hill and Jones, 1989; Browne et al., (1998); Andersen et al.,(1997) was adapted to the Turkish manufacturing firms. Manufacturing performance was assessed by seven items adapted from Li (2000); Hayes and Wheelwright (1984); Krajewski and Ritzman (1996); Hill (1994). To assess financial performance, a six-item scale was adapted from, Droge et al.,(1994); Clark (1982); Nobel(1995); Andersen et al., (1997); Calantone et al.,(2002); Kaynak (2003).

\section{Data Collection}

In order to empirically test the hypothesis, the data was collected from manufacturing firms in the Kocaeli region. Kocaeli is a major industrialized city in Turkey. A sample of 200 Turkish manufacturing firms in Kocaeli was contacted. The questionnaire was mailed to these 200 firms. One middle or upper manager from each company received the survey. Among those, 125 firms responded and filled out the survey form. Because of careless responses of the participants, 20 of the responses were eliminated. As a result, the response rate is 55 percent. Data is assessed through SPSS 13.0 for windows. The sample was $17,3 \%$ female, and $80,9 \%$ male. $87,1 \%$ of the respondents were university graduates. $24,5 \%$ of the respondents were general managers, $1,8 \%$ of the respondents were assistant general managers, $70,9 \%$ of the respondents were middle level managers. Several industries were included: food, textile, chemicals, basic metal, transport equipment, machinery and equipment, paper and paper products, and wood products. 


\section{Factor Analysis and Correlations}

Data were analyzed via exploratory factor analysis, Varimax rotation, to evaluate the unidimensionality of the construct. The findings of the factor analysis exposed a four-factor structure as expected, namely human resource management, marketing performance, manufacturing performance, and financial performance. The factor loadings supported the internal consistency since all the factor loadings were greater than 0.3 (Kim et al, 2004).

We used the Cronbach's Alpha to estimate internal consistency and reliability for the scales. Cronbach's alpha, a measure for testing the internal consistency or reliability of a set of two or more scale indicators (Cronbach, 1951), was computed for each set of measurements. The reliability coefficients for the human resource management, marketing, manufacturing and financial performance were, $0.88,0.71,0.80$, and 0.88 respectively. All of the Cronbach's alpha values were grater than recommended level of 0.70 (Nunnaly, 1978). We, therefore, decided that the measures have adequate internal consistency of each scale for use in further analyses. Also, in this study discriminant validity test was conducted. For this purpose, the average interscale correlations were compared to the Cronbach alphas. In this test, acceptable discriminant validity is present if the Cronbach alphas are greater than the interscale correlations (Bollen and Long, 1993). In our study, all of the Cronbach's alpha values were grater than the average interscale correlations.Results of discriminant validity test show that acceptable discriminant validity is present. The factor loadings and Cronbach's alpha values are displayed in Table I.

We also calculated means and standard deviations for each variable and created a correlation matrix of all variables used in hypothesis testing. Results of correlation analysis show that human resource management is positively related to both marketing performance and manufacturing performance. Besides, human resource management is positively related to financial performance. In order to investigate the combined effects of variables on financial performance, regression models were developed. The means and standard deviations are found to be within the expected ranges. The means, standard deviations, and results of correlation analysis are displayed in Table II.

\section{Hypothesis Testing}

The relationships among the variables were tested via multiple regression analyses. Regression models are as follows:

$\mathrm{OP}=\beta_{0}+\beta_{1} * \mathrm{MP}+\beta_{2} * \mathrm{MAN}+\mathrm{e}$

$\mathrm{OP}=\beta_{0}+\beta_{1} * \mathrm{MP}+\beta_{2} * \mathrm{HRM}+\mathrm{e}$

$\mathrm{OP}=\beta_{0}+\beta_{1} * \mathrm{MAN}+\beta_{2} * \mathrm{HRM}+\mathrm{e}$

$\mathrm{OP}=\beta_{0}+\beta_{1} * \mathrm{MP}+\beta_{2} * \mathrm{MAN}+\beta_{3} * \mathrm{HRM}+\mathrm{e}$

$(\mathrm{OP}=$ Financial performance, $\mathrm{MPR}=$ Marketing performance, MAN= Manufacturing performance, HRM=Human Resource Performance, e= error term)

In this study, correlation analyses were applied for one to one relationships. Results of correlation analyses indicate that human resource management is positively related to marketing performance $(\mathrm{r}=0.667 ; \mathrm{p}<0.01)$, manufacturing performance $(\mathrm{r}=0.731 ; \mathrm{p}<0.01)$, and financial performance $(r=0.593 ; p<0.01)$. Similarly, marketing performance is also found to be positively correlated with manufacturing performance $(\mathrm{r}=0.677 ; \mathrm{p}<0.01)$ and financial performance $(\mathrm{r}=0.623 ; \mathrm{p}<0.01)$. Manufacturing performance is also found to be strongly and positively correlated with financial performance $(\mathrm{r}=0.723 ; \mathrm{p}<0.01)$. Namely, all variables are positively related to both overall performance and to each other. According to correlation results, Hypotheses 1, 2, 3 are supported (see table II). 


\section{Table I. The Factors Loadings}

\begin{tabular}{|c|c|}
\hline Constructs and Items & \\
\hline Human Resource management(Cronbach's $\alpha: 0.88$ ) & Factor Loadings \\
\hline Increase professional training for managers & 0.877 \\
\hline $\begin{array}{l}\text { Increase employee's autonomy in performing their jobs } \\
\text { Increase job training for workers } \\
\text { Increase employee's task flexibility }\end{array}$ & $\begin{array}{l}0.854 \\
0.838 \\
0.777\end{array}$ \\
\hline Increase employee’s quality control responsibility & 0.743 \\
\hline $\begin{array}{l}\text { Establish compensation and recognition systems based on performance } \\
\text { Enhance employee-management relationship } \\
\text { Establish manual of production procedures and work rules }\end{array}$ & $\begin{array}{l}0.731 \\
0.680 \\
0.564\end{array}$ \\
\hline \multicolumn{2}{|l|}{ Marketing Performance (Cronbach's $\alpha: 0.71)$} \\
\hline $\begin{array}{l}\text { Establish brand name } \\
\text { Improve post-sale service } \\
\text { Improve pre-sale service } \\
\text { Improving firm reputation }\end{array}$ & $\begin{array}{l}0.762 \\
0.755 \\
0.754 \\
0.680 \\
\end{array}$ \\
\hline $\begin{array}{l}\text { Developing new promotion methods } \\
\text { Differentiating markets }\end{array}$ & $\begin{array}{l}0.523 \\
0.427 \\
\end{array}$ \\
\hline \multicolumn{2}{|l|}{ Manufacturing (Cronbach's $\alpha: 0.80$ ) } \\
\hline $\begin{array}{l}\text { Effectively arrange set-up schedules } \\
\text { Realize product mix flexibility } \\
\text { Reduce production scrap rate } \\
\text { Improve capacity utilization } \\
\text { Standardized number of parts used for manufacturing } \\
\text { Improve vendor's quality } \\
\text { Reduce inventory level }\end{array}$ & $\begin{array}{l}0.815 \\
0.758 \\
0.753 \\
0.737 \\
0.603 \\
0.558 \\
0.499 \\
\end{array}$ \\
\hline \multicolumn{2}{|l|}{ Firm Performance (Cronbach's $\alpha: 0.88$ ) } \\
\hline $\begin{array}{l}\text { Increase in profits } \\
\text { Increase in ROI } \\
\text { Increase in market share } \\
\text { Increase in sales } \\
\text { Increase in productivity }\end{array}$ & $\begin{array}{l}0.868 \\
0.844 \\
0.829 \\
0.825 \\
0.804 \\
\end{array}$ \\
\hline Increase in customer satisfaction & 0.584 \\
\hline
\end{tabular}

Table II: Descriptives, Correlations and Alpha Reliabilities of the Measures

\begin{tabular}{|c|c|c|c|c|c|c|c|c|}
\hline & Variables & Ort. & S.D. & Alpha & 1 & 2 & 3 & 4 \\
\hline 1 & HRM & 3.504 & 0.778 & 0.88 & 1.000 & & & \\
\hline 2 & Marketing Performance & 3.397 & 0.604 & 0.71 & $0.667 * *$ & 1.000 & & \\
\hline 3 & Manufacturing perform. & 3.546 & 0.662 & 0.80 & $0.731 * *$ & $0.677 * *$ & 1.000 & \\
\hline 4 & Financial performance & 3.669 & 0.689 & 0.88 & $0.593 * *$ & $0.623^{* *}$ & $0.723 * *$ & 1.000 \\
\hline $\mathrm{Co}$ & $\begin{array}{l}\text { lation is significant at } 0.0 \\
\text { tion is significant at } 0.05\end{array}$ & & & & & & & \\
\hline
\end{tabular}


We developed four regression models in order to test the other hypotheses in our study. In model 1, financial performance is the dependent variable and marketing performance, and manufacturing performance are the independent variables. Regression model 1, examining the effects of the performance of the marketing, and manufacturing on financial performance, was found statistically significant $(\mathrm{F}=57.367 ; \mathrm{p}<0.01)$. The results of regression model 1 indicate that both marketing performance $\left(b=0.215^{*} ;(p<0.05)\right)$ and manufacturing performance $\left(b=0.593^{* *} ;(p<0.01)\right)$ have a positive and significant effect on financial performance. When we look at the explanatory power of the model 1 , we see that the explanatory power of the model 1 is $\left(\mathrm{R}^{2}=0.572\right)$. This result shows that $57.2 \%$ of the financial performance changing stems from marketing and manufacturing performance.

\section{According to results of regression, Hypotheses 4, 5 were supported.}

In regression model 2 (RM2), we examined the effects of both the marketing performance of a firm and human resource management on financial performance. The results of regression model showed that marketing performance $\left(\left(\mathrm{b}=0.389^{* *} ;(\mathrm{p}<0.01)\right)\right.$ and human resource management $(\mathrm{b}$ $\left.=0.351^{* *} ;(\mathrm{p}<0.01)\right)$ have statistically significant positive effect on the financial performance of a firm.

"According to Baron and Kenny (1986), to test for mediation one should estimate the following three regression equations. First, the dependent variable is regressed on the independent variable, whereby the independent variable must affect the dependent variable (see correlation table for our study) to establish that there is an effect that may be mediated. Second, the mediator is regressed on the independent variable whereby the independent variable must affect the mediator. (see correlation table for our study ) Third, the dependent variable is regressed on both the independent variable and the mediator, whereby the mediator must affect the dependent variable (model 2) while controlling for the independent variable. If these conditions all hold in the predicted direction, a certain level of mediation exists. An additional fourth condition concerns a case of full mediation. Here the effect of the independent variable on the outcome variable controlling the mediator should be zero. If this effect is anything other than zero, a partial mediation is indicated" (Vigoda and Zion, 2004, pg.210).

In model 2, we investigated the mediating role of marketing performance in the relationship between human resource management and financial performance. According to correlation results, human resource management has significant effect on financial performance. When marketing performance is added to the equation in Model 2, the effect of the human resource management on financial performance is expected to be removed or reduced. But, in Model 2, the effect of human resource management on financial performance drops from (Correlation table; $(\mathrm{r}=0.593), ;(\mathrm{p}<0.01)$ to (Model 2; $\left(\mathrm{b}=0.351^{* *} ;(\mathrm{p}<0.01)\right)$ but still statistically significant. Therefore, we can conclude that marketing performance partially mediates the relationship between human resource management and financial performance. According to the results, Hypothesis 6 was not supported.

In regression model 3 (RM3), we examined the effects of both a firm's manufacturing performance and human resource management on financial performance. The results of regression analysis indicate that only manufacturing performance has statistically significant positive effect on a firm's financial performance. Effect of human resource on financial performance decreases from (Correlation table; $(\mathrm{r}=0.593)$; $(\mathrm{p}<0.01)$ to (Model 3; $(\mathrm{b}=0.149)$; $(\mathrm{p}>0.05)$ ) and becomes statistically insignificant, when manufacturing performance is added to the equation in model 3 . Therefore, it can be concluded that manufacturing performance is a fully mediating variable in the relationship between human resource management and financial performance. These findings met the condition for mediation that requires a relationship between the dependent and the independent variables. Consequently, Hypothesis 7 was supported.x 


\section{Table III. Regression Results}

\begin{tabular}{|c|c|c|c|c|c|c|c|c|}
\hline \multirow[b]{2}{*}{ Independents } & \multicolumn{2}{|c|}{$\begin{array}{l}\text { Model } 1 \\
\text { Financial performance }\end{array}$} & \multicolumn{2}{|c|}{$\begin{array}{c}\text { Model } 2 \\
\text { Financial performance }\end{array}$} & \multicolumn{2}{|c|}{$\begin{array}{l}\text { Model } 3 \\
\text { Financial performance }\end{array}$} & \multicolumn{2}{|c|}{$\begin{array}{c}\text { Model } 4 \\
\text { Financial performance }\end{array}$} \\
\hline & $\beta$ & $\mathrm{t}$ & $\beta$ & $\mathrm{t}$ & $\beta$ & $\mathrm{t}$ & $\beta$ & $\mathrm{t}$ \\
\hline Intercept & 0.555 & $1.856^{*}$ & 1.073 & $3.582 * *$ & 0.828 & $3.021 * *$ & 0.568 & $1.894^{*}$ \\
\hline Marketing performance & 0.215 & $2.247^{*}$ & 0.389 & $3.866 * *$ & - & - & 0.186 & $1.823^{*}$ \\
\hline Manufacturing perfor. & 0.593 & $6.189 * *$ & - & - & 0.615 & $5.954 * *$ & 0.543 & $4.857 * *$ \\
\hline HRM & - & - & 0.351 & $3.493 * *$ & 0.149 & 1.441 & 0.097 & 0.880 \\
\hline $\mathrm{F}$ & \multicolumn{2}{|c|}{57.367} & \multicolumn{2}{|c|}{40.695} & \multicolumn{2}{|c|}{53.800} & \multicolumn{2}{|c|}{38.402} \\
\hline $\mathrm{R}^{2}$ & \multicolumn{2}{|c|}{0.572} & \multicolumn{2}{|c|}{0.456} & \multicolumn{2}{|c|}{0.534} & \multicolumn{2}{|c|}{0.575} \\
\hline Adjusted $\mathrm{R}^{2}$ & \multicolumn{2}{|c|}{0.562} & \multicolumn{2}{|c|}{0.445} & \multicolumn{2}{|c|}{0.524} & \multicolumn{2}{|c|}{0.560} \\
\hline
\end{tabular}

$* *$ Coefficient is significant at 0.01

* Coefficient is significant at 0.05

In regression model 4 (RM4), we examined the effects of the performance of the marketing, manufacturing, and human resource on the financial performance. The results of regression model 4 showed that marketing $\left(\mathrm{b}=0.186^{*} ;(\mathrm{p}<0.05)\right)$ and manufacturing performance $\left(\mathrm{b}=0.543^{* *}\right.$; $(\mathrm{p}<0.01))$ have a statistically significant positive effect on a firm's financial performance, but human resource management does not have a statistically significant effect on the financial performance of a firm $(b=0.097 ;(p>0.05))$. Summary of the regression analyses results are displayed in Table IV.

\section{Table IV. Summary of Results}

\begin{tabular}{|c|c|c|c|}
\hline Number & Assertation & Acceptance & Rejection \\
\hline H1 & $\mathrm{HRM} \longrightarrow$ Marketing Performance & Correlation coefficient $\left(\mathrm{r}=0.667^{* *}\right)$ & \\
\hline $\mathrm{H} 2$ & $\mathrm{HRM} \longrightarrow$ Manufacturing performance & Correlation coefficient $(\mathrm{r}=0.731 * *)$ & \\
\hline $\mathrm{H} 3$ & HRM $\longrightarrow$ Financial performance & Correlation coefficient $\left(\mathrm{r}=0.593^{* *}\right)$ & \\
\hline $\mathrm{H} 4$ & $\mathrm{MP} \longrightarrow$ Financial performance & $\begin{array}{l}\text { Standardized Beta coefficient }(\beta \\
\left.=0.389^{* *}\right) \quad \text { Regression model } 2\end{array}$ & \\
\hline H5 & MAN $\longrightarrow$ Financial performance & $\begin{array}{l}\text { Standardized Beta coefficient }(\beta \\
\left.=0.389^{* *}\right) \text { Regression model } 2 \text { and } \\
\left(\beta=0.186^{* *}\right) \text { Regression model } 4\end{array}$ & \\
\hline H6 & $\mathrm{HRM} \longrightarrow \mathrm{MP} \longrightarrow$ Overall Perfor. & & $\begin{array}{l}\text { Correlation coefficient } \\
\left(\mathrm{r}=0.593^{* *}\right) \\
\text { Model 2's Standardized Beta } \\
\text { coefficient of HRM } \\
\left(\beta=0.351^{* *}\right)\end{array}$ \\
\hline $\mathrm{H} 7$ & $\mathrm{HRM} \longrightarrow \mathrm{MAN} \longrightarrow$ Overall Perfor & $\begin{array}{l}\text { Correlation coefficient }\left(\mathrm{r}=0.593^{* *}\right) \\
\text { Model 3's Standardized Beta } \\
\text { coefficient of HRM }(\beta=0.149 * *) \text { fully } \\
\text { mediated }\end{array}$ & \\
\hline
\end{tabular}




\section{CONCLUSION}

In this study, we examined the effects of the performance of the marketing, manufacturing, and human resource management functions on the financial performance of a firm. Furthermore, we examined the mediating effects of the marketing performance and manufacturing performance on the relationship between human resource management and financial performance. This study results provide empirical evidence to manufacturing managers of firms. Based on the findings, a number of guidelines can be offered to managers.

A main contribution of this study is that a meaningful relationship exists among human resource management, marketing performance, manufacturing performance and financial performance. When relationship between human resource management and marketing performance is examined, it can be seen that human resource management relates positively and significantly with marketing performance $(\mathrm{r}=0.667 ; \mathrm{p}<0.01)$. The finding is consistent with the findings reported in the literature (Brennan et al, 2003).

Human resource management is also found to be positively related to manufacturing performance $(\mathrm{r}=0.731 ; \mathrm{p}<0.01)$. This result supports the findings of many studies made in this field. For example; the research results of the study conducted by Challis and his colleagues (2005), indicate that organizational and human resource practices also explain significant additional variance in both employee and manufacturing performance. Jayaram et al (1999) found that HRM factors are strongly related to their respective manufacturing performance dimensions.

Furthermore, our study reveals that human resource management has significant effect on financial performance $(r=0.593 ; p<0.01)$. Our findings are consistent with the results of prior research. The literature has many studies in this field (Ahmad\&Schroeder, 2003; Goold\&Quinn, 1990; Dealaney\& Huselid, 1996; Levine\&Tyson, 1990; Becker\&Huselid's, 1998; Kleiner et al., 1987; Terspstra\&Rozell, 1993; Arthur 1992 ; Arthur, 1994; MacDuffie 1995; Batt 2002).

We also investigated the effects of the performance of the marketing and manufacturing on a firm's financial performance. The result of regression analyses reveals that both marketing performance and manufacturing performance have a positive effect on financial performance. According to the standardized $\beta$ coefficient (RM1), the most effective factor on the financial performance of the firm is manufacturing performance.

Moreover, mediating effect of marketing performance was also examined. It was revealed that marketing performance is a partially mediating variable on the relationship between human resource management and financial performance. In other words, human resource management affects financial performance both directly and through marketing performance.

Furthermore, the mediating effect of manufacturing performance was also examined. We conclude that manufacturing performance is a fully mediating variable in the relationship between human resource management and financial performance. In other words, human resource management affects financial performance only through manufacturing performance. The findings are significantly contributing to existing literature.

Besides, we examined the effects of the performance of the marketing, manufacturing and human resource on the financial performance. We found that marketing and manufacturing performance have a statistically significant positive effect on the financial performance of a firm. However, human resource management does not have a statistically significant effect on the financial performance of a firm. The results of regression analyses showed that manufacturing performance ( $\beta$ $=0.543 ; \mathrm{p}<0.01)$ has the most influence on financial performance. This result indicates that Turkish manufacturing managers have to effectively manage the manufacturing performance. The findings have significant importance for managers. The finding also supports to Kim and Arnold's (1993) studies.

In conclusion, our results indicate a significant relationship between marketing, manufacturing, human resource management, and financial performance. Nevertheless, manufacturing performance has the most influence on financial performance. Furthermore, marketing performance partially 
mediated and manufacturing performance fully mediated the relationships between human resource management and financial performance. These findings have important practical implication, as they are important for managers to understand which factors influence financial performance, so that they can choose which strategies to pursue and which actions to take to maximize financial performance. The empirical model is illustrated in Figure 2.

\section{Figure 2. Empirical Research Model}

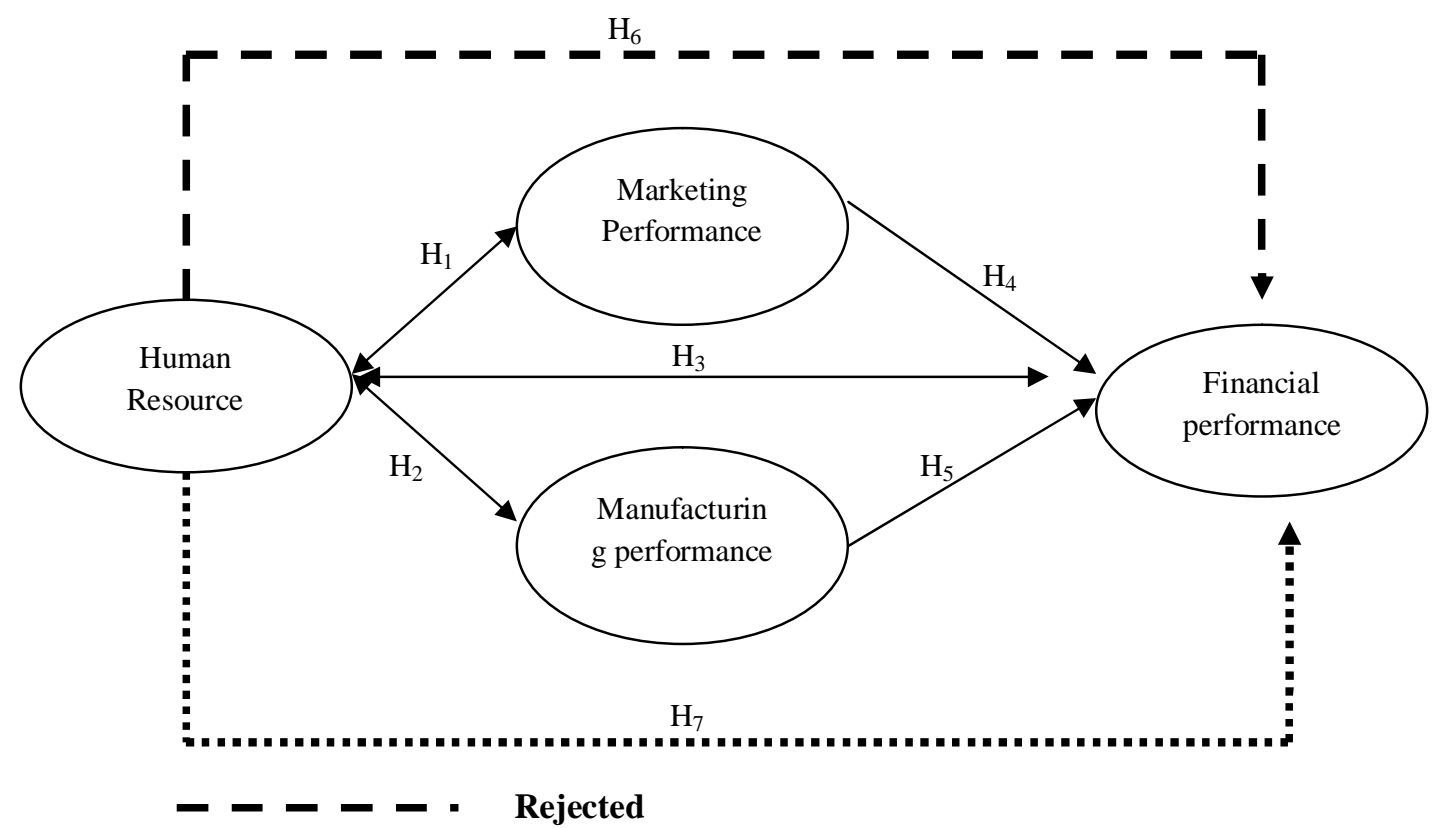

\section{LIMITATIONS AND FUTURE RESEARCH}

This paper has some limitations. One of the most important limitations of this study, even though we tried to contact more firms, time and budget constraints limited our study to only 110 firms. Sample size was not large enough to generalize the findings. Hence, the study needs to be replicated using a larger sample of firms. Second restriction of the study is the fact that the survey is applied to only one high level manager in the firms that we sampled. Probable perceptual differences among managers in a firm could have been eliminated by contacting more than one manager in the firm. In this way, the measurement error from the manager's perceptions could have been minimized. Due to the restriction of the economic sources, and the fact that the managers do not have much time to spare and were not willing to answer the survey, did not enable additional survey on the firms sampled.

There are many factors affecting financial performance. In this study, we explored the effects of human resource management, marketing performance, and manufacturing competence on financial performance by considering marketing performance and manufacturing competence as mediating variables between human resource management and financial performance. In the future research, we will investigate the effects of the other factors on financial performance with larger sample size.

In spite of these limitations, strengths of this study are present. For instance, in previous research, marketing and manufacturing performance mediating effects were not examined. In this study we examined mediating effect of marketing and manufacturing performance. The finding about the mediating effect significantly supports existing literature. 


\section{REFERENCES}

Ahmad, S. and R. G. Schroeder (2003). 'The impact of human resource management practices on operational performance: recognizing country and industry differences', Journal of Operations Management, 21, pp. 19-43.

Andersen, B., J. Browne, J. Devlin and A. Rolstadas (1997). 'Performance measurement: The ENAPS approach', The International Journal of Business Transformation, 1(2), pp.73-84.

Arthur, J.B. (1994). 'Effects of human resource systems on manufacturing performance and turnover', International Academy of Management Journal, 37,pp.670-687.

Arthur, J.B (1992). 'The link between business strategy and industrial relations systems in American steel minimills', Industrial and Labor Relations Review, 45; pp.488-506.

Baron, R. M. and D. A. Kenny (1986). 'The moderator-mediator variable distinction in social psychological research: conceptual, strategic, and statistical considerations', Journal of personality and social psychology, 6, pp.1173-1182.

Batt, R. (2002). 'Managing customer services: Human resource practices, quit rates, and sales growth', International Academy of Management Journal, 45, pp.587-597.

Becker, B. and M. A Huselid (1998). 'High performance work systems and firm performance. A synthesis of research and managerial implications. In:Ferris G.F.(ed):' Research in Personnel and Human Resources, 16, pp.53-101, Greenwich, CT:JAI Press, Inc.

Bello, D.C., and Gilliland, D.I.(1997). 'The effects of output controls, Process controls, and Flexibility on export channel performance', Journal of Marketing, 61, pp.22-38.

Bollen, K.A., and Long, J.J.(Eds).(1993). 'Testing structural equation models'. Sage, Newbury Park, CA.

Brennan, R., G.Felekis and D.Goldring (2003). 'Strategic management of marketing and human resources in further education colleges', Journal of Further and Higher Education, 27,(2), pp.143156.

Browne, J., J.Devlin., A. Rolstadas and B.Andersen (1998). 'Performance measurement - the ENAPS Approach', The International Journal of Business Transformation, 1(2), pp.73-84.

Buffa, E.S. (1984). 'Meeting the competitive challenge', Homewood, IL: Dow Jones, Irwin.

Calantone, R.J., S.T. Cavusgil and Y. Zhao (2002). 'Learning orientation, firm innovation capability, and firm performance', Industrial Marketing Management, 31(6), pp.515-524.

Capon, N., J.U. Farley and S. Hoenig (1990). 'Determinants of Financial Performance, A MetaAnalysis', Management Science, 36 (10), pp.1143-1159.

Cavusgil, S.T.and Zou, S.(1994). 'Marketing strategy-performance relationship: An investigation of the empirical link in export market venues', Journal of Marketing, 58, pp.1-21.

Challis, D., D. Samson and B. Lawson (2005). 'Impact of technological, organizational and human resource investments on employee and manufacturing performance: Australian and New Zealand evidence', International Journal of Production Research. London: Jan 1, .43, (1), pp. 81.

Clark, J.T. (1982). 'Selling top management-understanding the financial impact of manufacturing systems, American Production and Invertory Control Society Conference Proceedings', Fall Church, VA.

Conant, J. S., M. P. Mokwa and P. R. Varadarajan (1990). 'Strategic types, distinctive marketing 
competencies and organizational performance; A multiple measure-based study', Strategic Management Journal, 11(5), pp.365-383.

Cronbach., I.J.(1951). 'Coefficient Alpha and the Internal Structure of tests', Psychometrika, 16, pp.297-334.

Day, G.S. and L. Fahey (1988). 'Valuing market strategies', J. Mark; 52, pp.45-57 (july).

Day, G. S. and P. Nedungadi (1994). 'Managerial representations of competitive advantage', J mark, 58 (2), pp.31-44.

Delaney, J.T. and M. A. Huselid (1996). 'The impact of human resource management practices on perceptions of organizational performance', Academy of Management Journal, 39,(4), pp.949.

Droge, C., S. Vickery, and R. Marland (1994). 'Sources and outcomes of competitive advantage: an exploratory study in the furniture industry', Decision Sciences, 25,(5/6), pp.669-90.

Evans, J.R. and W.M.Lindsay (1996). 'The management and control of quality 3rd ed', West Publishing Co., St Paul, MN.

Flamholtz, E.G. and J.M. Lacey (1981). 'Personnel management, human capital theory, and human resource accounting', Los Angeles: Institute of Industrial Relations, University of California.

Goold, M., and J.J. Quinn (1990). 'The paradox of strategic goals', Strategic Management Journal, $11, \mathrm{pp} .43-57$.

Gummesson, E. (1991). 'Marketing-orientation revisited: The crucial role of the parttime marketer', European Journal of Marketing, 25(2), pp.60-75.

Haris, L.C. and E. Ogbonna (2001). 'Strategic human resource management, market orientation, and organizational performance', Journal of Business Research, 51, pp.157-166.

Hayes, R.H. and S.C. Wheelwright (1984). 'Restoring our competitive Edge', John Wiley\& Sons, New York, NY.

Hayes, R.H. and D.M. Upton (1988). 'Operations based Strategy', California Management Review, 40(4); pp.8-25.

Hill, C.W.L. and G.R. Jones (1989). 'Strategic Management Theory, An Integrated Approach', Houghton Mifflin, Boston, MA.

Hill, T. (1994). 'Manufacturing strategy, 2nd ed’, Irwin Professional, Burr Ridge, IL.

Houston, F.S. (1986). 'The marketing concept: What it is and what it is not', Journal of Marketing, 50(2), pp.81-87.

Huselid, M. (1995). 'The impact of human resource management practices on turnover, productivity, and corporate financial performance' Academy of Management Journal, 38; pp.635-672.

Jayaram, J., C. Droge and S.K. Vickery (1999). 'The impact of human resource management practices on manufacturing performance', Journal of operation Management, Columbia, 18(1), pp.1.b

Kaplan, R.S. and D.P. Norton (1993). 'The Balanced scorecard-measures that drive performance', Harvard Business Review, 71(9) (January/February).

Kaynak., H. (2003). 'The relationship between total quality management practices and their effects on firm performance', Journal of Operations Management, 21(4), pp.405-435. 
Kim, J.S. and P. Arnold (1993). 'Manufacturing competence and business performance: A framework and empirical analysis', International Journal of Operations\&Production Mangement, 13(10), pp.4-22.

Kim, M.K., M.C. Park, and D.H. Jeong (2004). 'The effects of customer satisfaction and switching barrier on customer loyalty in Korean Mobile Telecommunication Services', Telecommunications Policy, 28(2), pp.145-159.

Kleiner, M.M., R.N. Blocak, M. Roomkin and S.W. Salsburg (1987). 'Human resources and the performance of the firm', Madison, WI: University of Wisconsin.

Kohli, A.K. and B.J. Jaworski (1990). 'Market orientation: The construct, research propositions, and managerial implications', Journal of Marketing, 54(2), pp.1-18.

Kotler, P. and A.R. Andreasen (1996). 'Strategic Marketing for Non-profit Organizations (5th edn.)', Pearson Education /Prentice-Hall, Upper Saddle River, New Jersey.

Krajewski, L. and L. Ritzman (1996). 'Operations Management: Strategy and Analysis', AddisonWesley, Reading, MA.

Lado, A.A. and M.C. Wilson (1994). 'Human resource systems and sustained competitive advantage: a competency-based perspective', Academy of Management Journal, 19 (4), pp.699-727.

Lai, K., and T. C. E. Cheng (2005). 'Effects of quality management and marketing on organizational performance', Journal of Business Research 58, pp.446-456.

Lajara, B.M., L. Garcia and V.S. Sempere (2003). 'Human resoucres management: A success and failure factor in strategic alliances', Employee Relations, 25,(1/2), pp.61-80.

Levine, D. and L. D. Toyson (1990). 'Participation, productivity, and the firm's environment', In A.S. Blinder (Ed.), Paying for productivity: 183-244. Washington, DC: Brookings Institution.

Li, X. L. (2000). 'An analysis of sources of competitiveness and performance of Chinese manufactures'. International Journal of Operations \& Production Management, 20(3), pp.299-315.

Liao, Y.S. (2005). 'Business strategy and performance: the role of human resource management control', Personel Review, 34(3), pp.294.

Macduffie, J.P. (1995). 'Human resource bundles and manufacturing performance; organizataional Logic and flexible production systems in the World Auto Industry', International Industrial and Labor Relations Review, 48, pp.197-221.

Morgan, N.A., B.H. Clark and R. Gooner (2002). 'Marketing productivity, marketing audits, and systems for marketing performance assessment, Integrating multiple perspectives', Journal of Business Research 55, pp.363-375.

Mount, M., Ilies, R., and Johnson, E. (2006). 'Relationship of personality traits and counterproductive work behaviors; the mediating effects of job satisfaction', Personnel Psychology; 59(3), pp.591-600.

Ngai J.C.H. and P. Ellis (1998). 'Market orientation and business performance: some evidence from Hong Kong', Int Mark Rev, 15(2), pp.119-38.

Nobel, M.A. (1995). 'Manufacturing strategy: testing the cumulative model in a multiple country context', Decision Sciences, 26(5) ,pp.693-718.

Nunnally, J. C. (1978). 'Psychometric theory', 2nd edition. McGraw-Hill, New York. 
Perreault Jr. W.D. and E.J. Mcarthy (1999). 'Basic Marketing: A Global- Managerial Approach', Irwin-McGraw Hill, New York.

Porter, M.E.(1990). 'The competitive advantage of Nations', The Free Pres, New York, NY.

Raju, P.S. and S.C. Lonial (2002). 'The impact of service quality and marketing on financial performance in the hospital industry: an empirical examination', Journal of Retailing and Consumer Services, 9, pp.335-348.

Roth, A. and J.G. Miller (1990). 'Manufacturing strategy, Manufacturing strength, managerial success and Economic outcomes', in Ettlie, J.E., Burstein, M.C. and Fiegenbaum, A.,(Eds), Manufacturing strategy, Kluwer, Boston, MA, pp.97-108.

Simerly, R.L (1997). 'Human resource management and economic performance: a strategic management approach', International Journal of Management, 14(2), pp.282-91.

Skinner, W. (1969). 'Manufacturing: The missing link in corporate strategy', Harvard Business Review, May/June, pp. 136-145.

Snell, S.A.and Dean, J.W.,Jr. (1992). 'Integrated manufacturing and human resource management: A human capital perspective', Academy of Management Journal ,35(3), pp.467.

Swamidass, P.M. and W.T. Newell (1987). 'Manufacturing strategy, environmental uncertainty and performance: a path analytic model', Management science, 33 (4), pp.509-524.

Szymanski, D.M., Bharadwaj, S.G., and Varadarajan, P.R.(1993). 'An analysis of the market shareprofitability relationship', Journal of Marketing, 57(July), pp.1-18 .

Terpstra, D.E., and Rozell, E.J.(1993). 'The relationship of staffing practices to organizational level measures of performance', Personnel Psychology, 46, pp.27-48.

Venkatraman, N. and Ramanujam, V.(1986). 'Measurement of business performance in strategy research: A comparison of approaches', Academy of Management Review, 11(4), pp.801-814.

Vigoda-G.E and E.B.Zion.(2004). 'Bright shining stars: The mediating effect of organizational image on the relationship between work variables and army officers' intentions to leave the service for a job in high-tech industry', Public Personnel Management, 33(2), pp.201.

Walker, O.C., Jr, and Ruekert, R.W.(1987). 'Marketing's role in the implementation of business strategies: A critical review and a conceptual framework', Journal of Marketing, 51(July), pp.15-33.

Wang, C.H. (1993). 'The impact of manufacturing performance on firm performance, the determinants of manufacturing performance, and the shift of the manufacturing efficiency frontier', Ph.D., State University of New York at Buffalo, 233 pages.

Youndth, M., S.C. Snell, J. Dean and D. Lepak (1996). 'Human resource management, manufacturing strategy, and firm performance', Academy of Management Journal, 39(4), pp.836. 